\title{
Effects of Articulation Therapy using Oral Motor Training on the Articulation Accuracy and the Lateralization Distortion Errors of Children with Class III Malocclusion
}

\author{
Sangkyung Lee', Sungsoo Kim² \\ ${ }^{1}$ EZ Speech-Language Therapy Center, Gwangju, Korea \\ ${ }^{2}$ Department of Speech Therapy, Dongshin University, Naju, Korea

\begin{abstract}
구강운동 훈련을 사용한 조음 치료가 3급 부정교합 아동의 조음 정확도 향상과 설측음화 왜곡 오류 감소에 미치는 효과
\end{abstract} \\ 이 상 경 $\cdot$ 김 성 수 ${ }^{2}$ \\ 이지의사소통연구소 ${ }^{1}$, 동신대학교 언어치료학과 ${ }^{2}$
}

\begin{abstract}
Purpose: The goal of this study is to examine the effect of articulation treatment using Oral Motor Training (OMT) on articulation accuracy and distortion errors of children who have speech sound disorders with class III malocclusion. Methods: Three children with class III malocclusion in the stage of deciduous dentition aged from 6;0-6;3 (year;month) participated in this study. These 3 children commonly exhibited unilateral mastication, mandible laterality on jaw movement and especially distortion errors of lateralizing for alveolar and palatal consonants mainly in vowel /i/ environment. Articulation therapy using OMT for both of improved non-speech and speech movement involved in target sound production was provided. The ABA design of single case experimental design was used. The articulation accuracy and the frequency of lateralization distortion errors at both of the word and sentence level were measured within baseline (A1), intervention (B), and maintenance (A2) phases. Results: It was found that all participants showed the higher articulation accuracy and the lower frequency of distorted lateralization errors for alveolar and palatal consonants at the both of word and sentence levels in intervention phases than in baseline ones and also these effects maintained after intervention. Conclusion: It was concluded that the OMT targeting appropriate non-speech and speech movement might be beneficial for young children who have class III malocclusion.
\end{abstract}

Key Words: Speech sound disorders, Articulation therapy, Class III malocclusion, Oral motor training.

Received: October 2, 2017 / Revised: October 18, 2017 / Accepted: October 18, 2017

Correspondence: Sungsoo Kim, Department of Speech Therapy, Dongshin University, 185 Geonjae-ro, Naju 58245, Korea

Tel: +82-61-330-3472 / Fax: +82-61-330-3476 / E-mail: supeech@gmail.com

\section{INTRODUCTION}

3급 부정교합자는 반대 교합, 하악 돌출의 구조적인 결함으 로 인해 조음 문제를 나타낼 수 있다(Lee \& Kim, 1993; Yang, 1996). 이 중 유치열기 아동의 경우, 상하악의 발육 정도, 영구 치 맹출 시기, 하악의 폐구 양상, 하악의 전방 가능성이 성숙과 함께 변화하면서 저작, 연하 및 조음에 관여되는 구강운동의 기능이 전형성에서 벗어나게 되는 경우가 많아 말소리의 오조
음이 발생되기도 한다(Jung et al., 2015).

3 급 부정교합 아동에게서 주로 발생하는 말소리 오류에는 조음 위치 측면에서 치조음의 왜곡이 있으며, 조음 방법 측면에 서는 마찰음의 왜곡이 보고된다. 이들이 지니는 구조적인 문제 로서의 반대교합은 치조 마찰음 $/ \mathrm{s} /$ 의 말소리 왜곡을 가져오는 경우가 많고, 치찰음 $/ \mathrm{s} /, / \mathrm{z} /$ 에서 혀 짧은 소리(lisping)를 내는 왜곡이 나타나기 쉬우며, /th/, /1/의 왜곡이 나타나기도 한다 (Laine, 1987; Laine, 1992). 이는 정상교합자에 비해 혀의 위치 
가 하방에 위치하여 혀끝을 상악 치조 부근으로 들어올리는 움직임이 한정된 범위에서 이루어짐에 따라 발생하는 문제로 설명되기도 하고(Lee \& Kim, 1993; Yang, 1996), 개교합이 동 반된 경우 보상적 조음의 일환으로 정상교합자에 비해 하악을 더 넓은 범위까지 움직여 조음하게 된 결과로서 보고되기도 한 다(Johnson \& Sandy, 1999; Laine, 1987). 이러한 말소리 오류 에는 구강 습관이 동반된 경우도 흔하다. 유치열기의 어린 아동 들에게서는 농설벽(tongue thrust)과 흡지벽(thumb sucking), 그리고 편측 저작과 같은 잘못된 습관이 동반되는 경우가 많은 데(Jung et al., 2015), 이 경우 연하 시 혀를 내밀게 되어 치찰음 을 발음할 때 혀를 치간에 위치시켜 말소리를 왜곡하는 사례도 있다(Laine, 1987). 드물게 보고되지만 반대교합이 심한 경우, 상악의 전치부를 아랫입술에 접촉하는 움직임의 범위에 제한 이 생겨 순치 마찰음 $/ \mathrm{f} /, / \mathrm{v} /$ 를 산출하는 데 어려움이 따르기도 한다(Laine, 1987).

이처럼 선행연구에서 보고된 사례들을 보면, 3 급 부정교합 아동에게서 발생하는 말소리 오류의 문제는 하악의 과도한 움 직임이나 혀의 습관적인 전방화, 잘못된 혀 위치 및 제한된 혀 움직임의 범위에서 오는 것임을 생각해 볼 때 구강운동 기능 (oral motor function)과 밀접한 연관이 있음을 알 수 있다.

구강 구조의 기질적인 결함으로 인하여 조음기관의 위치와 움 직임에 문제가 초래되어 말소리 오류가 발생한 경우, 조음 개선 을 위해 구강운동 훈련(oral motor training, OMT)을 사용한 조 음 치료를 실시하여 그 효과성을 보고한 사례들이 있다. Lee \& $\operatorname{Kim}(2001)$ 은 구강자음을 성문 파열음으로 보상 조음하는 구 개파열 아동을 대상으로 성대 이완 훈련을 병행한 형성기법 접 근의 조음 치료를 실시한 결과, 이들에게서 흔히 발생하는 성문 파열음이 감소되고 조음 정확도가 향상되었음을 보고하였다. Sargenti(2011)는 불충분한 구강운동 조절 능력을 보이고 치찰 음 $/ \mathrm{s} /$ 와 $/ \mathrm{z} /$ 를 치간과 설 측의 혀 짧은 소리로 왜곡하는 말소리 장애 아동을 대상으로 $\mathrm{OMT}$ 와 조음 치료를 실시한 결과 오류 음소의 개선과 구강운동 기능의 향상이 있었다고 하였다. Derakhshandeh et al.(2016)은 구개열과 연인두 기능부전이 있는 아동들을 대상으로 $\mathrm{OMT}$ 를 포함한 음성적 접근 및 음운적 접 근의 조음 치료를 실시하는 것이 이들에게서 나타난 전형적인 비구어적 특성과 오조음을 개선하고 조음 정확도의 향상에 효 과를 가져올 수 있음을 보고하였다.

OMT는 호흡, 발성, 공명, 조음의 기전에 관여하는 턱, 입술, 혀, 연인두의 운동 연습을 통해 말소리 산출에 요구되는 각 기 관의 특정 위치 및 움직임의 개선에 효과적인 것으로 보고가 되고 있어, 불충분한 구강운동이 기저한 말소리 장애 치료에 자주 사용되는 접근 방식이다(Bahr \& Rosenfeld-Johnson, 2010; Lohman-Hawk, 2007). 특히 OMT는 비구어적 훈련만
을 독립적으로 실시하기보다는 구어 과제에 접목되었을 때 특 정 말소리 산출을 위한 구강운동 기능에 대한 인식과 정확성, 조음기관 간의 협응에 유익하다(Lohman-Hawk, 2007).

그러므로 구강 구조의 기질적 결함이 기저하며 구강운동 기 능에 문제를 보이는 3 급 부정교합을 가진 말소리 장애 아동의 경우에는 조음 치료에 OMT의 적용을 고려해 볼 수 있을 것이 며, 비구어적 훈련만을 별도로 실시하기보다는 목표 말소리 산 출에 직접적으로 요구되는 조음기관의 움직임에 관한 훈련을 포함시키는 것이 바람직할 것이다.

지금까지 3 급 부정교합 아동의 말소리 장애 사례 보고가 거 의 드물었고, 여러 변인의 조합을 고려한 치료 내용 역시 보고 된 바가 없어서 적절한 치료 전략을 알아보는 데 한계가 있었다. 본 연구에서는 3 급 부정교합을 가진 말소리 장애 아동을 대상 으로, 구강운동 기능의 평가, 문맥에 따른 말소리 오류 패턴을 분석하여, 부정교합의 기질적 문제 및 관련 구강운동을 고려한 조음 치료를 실시하여 그 효과를 확인함으로써 3급 부정교합 아동의 말소리 왜곡 오류에 대한 적절한 치료 전략을 알아보고 자 하였다.

이를 위해 본 연구에서는 구강운동 훈련을 사용한 조음 치 료가 3 급 부정교합 아동의 조음 정확도 향상과 설측음화 왜곡 오류의 감소 및 유지에 효과가 있는가를 밝히고자 하였다.

\section{MATERIALS AND METHODS}

\section{연구 대상}

본 연구는 소아치과에서 3 급 부정교합으로 진단받은 뒤 언 어평가에 의뢰된 유치열기의 아동들 중 공통적으로 /이/ 모음 환경에서의 치조음 /ㄷ/, /匹/, /E/, /ㄴ/, /ㄹ/, /ㅅ/, /ㅆ/ 및 경구개 음 /ㅈ/, /ㅉ/, /ㅊ/의 설측음화 왜곡 오류를 보이는 말소리 장애 아동 3명을 대상으로 하였다. 대상 아동은 모두 공통적으로 편 측 저작 습관과 편측화된 하악 폐구 습관을 지니고 있었으며, 소아치과 전문의로부터 10 세가 되기 전 1년 이상의 교정 치료를 받을 것과 그 이후 악안면 성장의 완성 및 영구치 맹출 상태에 따라 치아교정이나 악교정수술 시행 여부를 협의하기 위해 추적 진료를 받을 것을 권고받았다. 현재 아동의 위축된 정서와 또래 관계의 문제, 그리고 교정의 효과 예후를 위한 확진 시기, 말소 리 장애에 대한 부모의 근심도를 고려하여 교정에 대한 아동의 동기 유발 및 올바른 구강 습관과 조음 치료를 위해 장치 착용 에 우선하여 OMT가 포함된 말소리 장애 치료 실시가 협의되었 다. 3 명의 대상 아동 모두 남자 아동으로 생활연령은 6세 0 개월 에서 6세 3개월의 범위에 있었으며 취학 전 아동의 수용언어 및 표현언어 발달 척도(Preschool Receptive Expressive Language Scale) (Kim et al., 2013) 평가 결과, 수용 및 표현 언어능력에서 
백분위수가 $94 \%$ 이상에 해당하여 언어능력에는 문제가 없었 다. 이 외에 특기할 만한 발달력, 병력, 가족력은 없었으며 청력 상의 문제 역시 없었다. 대상자는 모두 연구의 목적 및 절차에 대한 설명을 듣고 연구 참여 동의서에 서명을 한 후 연구에 참 여하였다. 전체 대상 아동의 배경 정보는 Table 1 에 제시되었다.

\section{3급 부정교합 아동 $\mathrm{A}$ 의 배경정보}

대상 아동 $\mathrm{A}$ 는 생활연령 6 세 3 개월의 남자 아동으로, 구강안 면근기능평가 프로토콜(orofacial myofunctional evaluation, OME) (Felício \& Ferreira, 2008)과 비구어 과제 구강운동 기능 평가(assessment of oral motor functions during non-speech tasks, AOMF) (Mackie, 1996)로 평가한 결과 전치부 반대교 합, 안면 비대칭, 턱 개폐 시 하악의 편측성 및 편측 저작 습관, 삼킴 시 혀 내밀기가 관찰되었다. 아동용 발음평가(Assessment of Articulation and Phonology for Children, APAC) (Kim et al., 2007) 결과 낱말 자음 정확도 $85.7 \%$, 백분위수 $1 \%$ 미만이었 다. 아동의 주된 말소리 왜곡인 /이/ 모음 환경에서의 '치경음과 경구개음의 설측음화'는 조음 음운 발달 과정에서 나타나는 오류가 아닌 비전형적인 오류에 해당하는 것으로 평가되었다. /이/ 모음을 제외한 모음 환경에서 치경 마찰음의 치간음화 오 류가 나타났으나 이는 나이에 적절한 오류 패턴인 것으로 평가 되었다. 검사하는 동안 아동 $\mathrm{A}$ 의 조음을 관찰한 바에 의하면, /이/ 모음이 포함된 음절을 조음할 때 하악이 편측으로 치우친 채로 닫히는 모습이 보였고 치경 파열음, 치경 파찰음, 치경 마 찰음, 경구개 파찰음 조음 시 편측으로 침이 고이며 기류가 방 출됨으로써 소음성이 강한 말소리가 산출되었다. 이는 시각적, 청각적으로 상당히 두드러진 인상이었다. 아동의 부모는 아동 의 발음과 위축된 정서가 또래 관계에 부정적인 영향을 미치고 있음을 심히 우려하고 있어 말소리 장애에 대한 근심도가 상당 히 깊었다.
3급 부정교합 아동 $\mathrm{B}$ 의 배경정보

대상 아동 $\mathrm{B}$ 는 생활연령 6세 1개월의 남자 아동으로, 구강 안면근 기능평가 프로토콜(OME) (Felício \& Ferreira, 2008) 과 비구어 과제 구강운동 기능평가(AOMF) (Mackie, 1996) 평 가 결과, 안면 비대칭과 전치부 개교합이 있었으며, 편측 저작 습관, 턱 개폐시 하악의 편측성이 관찰되었으며 농설벽과 삼킴 시 혀내밀기가 관찰되었다. 아동용 발음평가(APAC) (Kim et al., 2007)에서 낱말 자음 정확도가 $84.3 \%$, 백분위수는 $1 \%$ 미만 이었으며. 아동의 주된 말소리 왜곡인 /이/ 모음 환경의 '치경음 과 경구개음의 설측음화'가 조음 음운 발달 과정에서 나타나는 오류가 아닌 특이한 오류 패턴인 것으로 평가되었다. /이/ 모음 을 제외한 모음 환경에서 나타난 치경 마찰음의 치간음화 오류 는 아동의 나이에 적절한 오류 패턴인 것으로 나타났다. 아동 $\mathrm{B}$ 는 조음할 때 간혹 편측으로 침이 고이다가 입가에 흐르는 모습 이 관찰되었고, /이/ 모음이 포함된 음절을 조음할 때 하악이 편 측으로 치우친 채로 닫히는 모습이 보였으며, 치경음 및 경구개 음에서 파열, 파찰, 마찰의 방법으로 조음할 때 편측으로 침이 튀는 모습이 관찰되었다. 유치원 교사의 보고에 의하면, 아동은 평소에 말수가 적으며 교실 담화 상황이나 또래 간 의사소통 상 황에서 발음 문제로 인한 대화 실패나 거부가 있을 경우 대화 복구 시도를 단념한 채 상호작용에 위축을 나타낸다고 하여 사 회정서적인 측면에서 2차 문제가 유발될 위험이 있어 보였다.

\section{3급 부정교합 아동 $\mathrm{C}$ 의 배경정보}

대상 아동 C는 생활연령 6세 0개월의 남자 아동으로, 구강안 면근 기능평가 프로토콜(OME) (Felício \& Ferreira, 2008)과 비구어 과제 구강운동 기능평가(AOMF) (Mackie, 1996)를 사 용한 평가 결과 전치부 반대교합, 하악 비대칭 및 턱 개폐 시 하 악의 편측성이 관찰되었으며 편측 저작 습관이 있었다. 아동용 발음평가(APAC) (Kim et al., 2007)에서 낱말 자음 정확도가 $85.7 \%$ 로 백분위수 $1 \%$ 미만에 해당하였고, 아동의 주된 말소리

Table 1. Background information of three children with class III malocclusion

\begin{tabular}{llll}
\hline Characteristics & \multicolumn{1}{c}{ Child A } & \multicolumn{1}{c}{ Child B } & Child C \\
\hline Chronological age (year;month) & $6 ; 3$ & $6 ; 1$ & M \\
Gender & $\mathrm{M}$ & $\mathrm{M}$ & Mandible asymmetry \\
OME \& AOMF & Face asymmetry & Face asymmetry & Anterior crossbite \\
& Anterior crossbite tongue thrust & Anterior openbite tongue thrust & Unilateral mastication \\
& Unilateral mastication & Unilateral mastication & Laterality in JM \\
PCC (\%) & Laterality in JM & Laterality in JM & $85.7(<1 \%$ ile) \\
PRES-R (\%) & $85.7(<1 \%$ ile) & $84.3(<1 \%$ ile) & 96.0 \\
PRES-E (\%) & 98.0 & 98.0 & 94.0
\end{tabular}

OME: orofacial myofunctional evaluation (Felício \& Ferreira, 2008), AOMF: assessment of oral motor functions during non-speech tasks (Mackie, 1996), JM: jaw movement, PCC: percentage of correct consonants, PRES-R: Preschool Receptive-Expressive Language Scale-(Receptive), PRES-E: Preschool Receptive-Expressive Language Scale-(Expressive) 
왜곡인 /이/ 모음 환경의 '치경음과 경구개음의 설측음화'가 비 전형적인 오류 패턴인 것으로 평가되었다. /이/ 모음을 제외한 모음 환경에서 나타나는 치경 마찰음의 치간음화 오류는 나이 에 적절한 오류 패턴인 것으로 나타났다. 아동 $\mathrm{C}$ 는 /이/ 모음이 포함된 음절을 조음할 때 하악이 편측으로 치우친 채로 닫히 는 모습이 보였으며, 편측 설측음화를 보일 때 소음성이 강한 소리를 산출하는 것이 관찰되었다. 부모 보고에 따르면, 아동이 청각적으로 거슬리는 소리를 내며 발음을 하여 또래 모임에서 제외된 경험과 놀림을 받은 경험이 있었는데, 이에 아동은 크 게 개의치 않고 의사소통 시도를 많이 하였고 말수 또한 많았 었다고 한다. 그러나 최근에 또래로부터 대화 참여에 거부되는 경우가 잦았으며, 또래들에게 부정적인 말과 다소 공격적 행동 을 아동이 보인다고 하였다.

\section{연구 도구}

\section{중재 도구}

본 연구의 OMT를 사용한 조음 치료는 4단계로 구성하여 진 행되었다. 각 단계의 구성은 조음을 위한 혀끝 및 혀 등위의 위 치와 움직임에 의거하여 목표음을 분류하여 단계를 나눈 후 Hoch et al.(1986)의 목표음 설정 준거를 참고하여 자극 반응도 (stimulability)가 높은 음소와 음소 습득 시기를 고려하여 단계 의 순서를 정하였다. 1단계는 경구개음 /ㅈ/, /ㅉ/, /ㅊ/ 단계, 2단 계는 /ㄷ/, /匹/, /E/ 단계, 3단계는 /ㄴ/, /리 단계, 4단계는 / ㅅ/, /씨단계였으며, 각 단계는 3회기마다 다음 단계로 넘어가도록 하였다.

$\mathrm{OMT}$ 는 비구어적인 $\mathrm{OMT}$ 와 구어적인 $\mathrm{OMT}$ 로 구성되어 각 단계의 모든 수준, 모든 회기마다 실시되었다. 비구어적인 OMT 는 목표 말소리에 직접적 관련이 없는 턱과 입술 및 혀의 위치 와 움직임에 관한 활동이었다. 이러한 비구어적인 OMT를 실시 한 다음에는 곧바로 해당 회기의 목표 말소리 조음에 직접적으 로 요구되는 구어적 OMT를 실시하였다. 본 연구에서의 목표행 동은 /이/ 모음 환경에서의 목표음의 정조음, 그리고 왜곡 오류 의 감소였으므로, $\mathrm{OMT}$ 역시 정확한 목표 말소리 산출에 요구 되는 구강운동 기능의 개선에 초점을 두어 구어 산출에 필요한 움직임을 훈련하였으며, 이는 언어 단위별 수준에 적용되어 주 로 모음 훈련과 음절 수준에서 집중적으로 실시되었다.

목표음에 대한 치료는 구강운동 연습과 연계한 모음 훈련음절 수준-단어 수준-문장 수준의 순서로 실시하도록 하였다. 구강운동 연습과 연계한 모음 훈련에서는 비구어적인 턱 개폐 및 혀 운동으로부터 올바른 폐구를 유도하여 조음기관의 바른 위치와 움직임을 연습한 후, 준비된 위치에서 /이/ 모음 산출을 도입하였다. 즉, 먼저 혀 끝 및 등위(tongue tip and dorsum)의
앞부분을 상악의 치경 및 경구개에 접촉시켜 삼킴 동작을 하고, 즉시 이어서 혀끝을 치경에 접촉시킨 채로 하악을 직립으로 개 방하고 닫는 반복 연습을 한다. 그 다음 하악 개구 시 혀 위치가 전방 및 후방이나 측방으로 치우치지 않도록 바르게 위치시키 고 하악의 폐구 시 혀끝을 내리면서 혀 양옆 가장자리(margin of lateral)를 상악의 양측 구치부에 접촉하는 반복 훈련을 통해 /이/ 모음 산출을 유도하였다. 음절 수준에서는 전통적인 음성 적 접근법의 기법들을 사용하여 '목표음 $+/$ 이' 산출을 위한 조음점 지시법, 목표음과 왜곡음의 청각적 변별을 통한 목표음 확인 전략을 적용하였다. 그리고 형성 기법을 사용하여, 음소 수준에서 목표음을 무성음으로 산출하게 하다가 모음 / 이/를 이어서 유성음으로 산출하도록 하였다. 예를 들어, /ㅈ/을 성대 진동 없이 산출하는 도중에 성대 진동을 첨가하면서 올바른 턱 위치와 혀 위치에서 /이/를 산출하게 하고, 점차 /지/의 음성 시 작 시간을 줄여서/지/를 정확하게 사용하도록 유도하였다. 단음 절 훈련 뒤, 습관화된 왜곡 조음 방식을 완화하고 개모음 뒤에 이어지는 /이/ 모음 포함의 음절 조음에 요구되는 구강운동 기 능을 강화하기 위해 다음절의 무의미 음절(nonsense syllables) 을 앞서와 같은 방식으로 진행하고, 무의미 음절의 정확한 산출 을 유도하는 보드게임 활동의 규칙을 통해 승패로서 정조음을 강화하였다. 아동이 ‘목표음 $+/$ 이/'가 포함된 다양한 조합의 무 의미 음절 산출을 5 회 이상 연속하여 정확하게 산출하면, 단어 수준으로 넘어가 /이/ 모음 환경의 목표 음소가 포함된 단어를 어두 초성에서 산출하게 하였고, 정확히 산출하면 어중 초성에 서 산출하게 하였다. 이 과정에서 만일 아동이 정확하게 산출하 지 못할 경우, 음절 수준에서와 마찬가지로 목표 무성음과 /이/ 모음 유성음을 이어서 산출하도록 하여 단어 내/이/ 모음 환경 의 목표음을 정확하게 산출하도록 유도하였으며, 빙고게임과 퍼 즐 맞추기 활동에서의 규칙을 통해 승패로서 정조음 산출을 강 화하였다. 아동이 단어 수준에서의 훈련 놀이(drill play) 활동 시 3회 이상 정확하게 목표 단어를 산출하면 문장 수준으로 넘 어가 문장 산출을 유도하였으며, 정확하지 않을 경우 단어 수 준에서와 마찬가지의 절차를 거쳐 목표 음소를 정확하게 사용 하게 하였다. 문장 수준에서도 음절 및 단어 수준에서와 마찬가 지로 게임의 승패로서 정조음 산출을 강화하였으며, 문장 수준 의 게임에는 운반구(carrier phrase) 사용 규칙이 포함되었다.

중재의 매 회기마다 그림 및 설명이 포함된 비구어적 구강운 동 과제를 제공하였으며, 부모에게도 제시하고 과제 수행은 $\mathrm{SNS}$ 를 통해 확인하였다. 가정에 제공하는 과제의 그림 자료는 Oral-Motor Activities for Young Children (Mackie, 1996)과 “Can Do" ${ }^{\circledR}$ Oral-Motor Fun Deck ${ }^{\circledR}$ (Joanne \& Kim, 1997)를 활용하였다. 구강운동 기능 훈련을 사용한 조음 치료 프로토콜 은 Figure 1에 제시되었다. 


\section{평가 도구}

기초선, 중재, 유지에 걸친 전체 실험 회기에서 매 회기마다 목 표음의 조음 정확도와 설측음화 왜곡 오류 빈도를 알아보기 위 해 조음검사를 실시하였다. 조음검사는 우리말 조음·음운 학습 기본 자료집(Urimal Workbook of Articulation and Phonology) (Shin \& Kim, 2007)에서 2 6세 아동의 발음 색인의 단어 를 참고하여 제작하였다. 전체 대상 아동이 공통적으로 오조음 하여 목표 음소로 선정되었던 /이/ 모음 환경의 치경음 및 경구 개음 10 개에 대하여 단어와 문장 수준에서의 목표 말소리를 평 가하였다. 단어 목록은 각 음소별로 목표 음소가 초성에 포함 된 단어와 어중 초성에 포함된 단어를 2 3음절로 2개씩 구성하 여 총 40 개를 작성하였다. 문장 목록은 단어 목록 내의 단어가 포함된 2어절의 간단한 문장 40 개를 작성하였다. 단어 및 문장 목록은〈Appendix〉와 같다.

말소리 평가는 언어재활사(1급) 자격을 소지한 5년 이상 경력 의 석사학위를 가진 검사자가 실시하였다. 검사자는 아동에게 우리말 조음 음운 학습 기본 자료집의 그림을 제시하여 아동이 해당 그림의 단어를 자발적으로 산출하게 하였다. 아동이 단어 를 자발적으로 발화하지 못할 경우, 언어적 단서를 주어서 발 화를 유도하였다. 문장 수준의 검사는 우리말 조음 음운 학습 기본 자료집의 그림과 클립아트를 활용하여 “뭐해요?”, “어떤 소리가 나요?”, “어떻게 달려요?”라고 질문하여 목표 말소리를 산출하게 하였다. 아동이 산출하는 문장의 어절 수를 통제하기 위해 문장 조각(sentence strips) 차트를 제시하여 2어절로 발 화하도록 지시하고 유도하였다. 단어 및 문장의 제시 순서는 매 회기마다 역균형화되도록 하였으며, 각 목록 내 순서 역시 무작 위로 제시하였다. 중재 단계에서의 검사는 중재자의 중재가 끝 난 다음에 검사자가 별도로 실시하였다. 검사에 소요된 시간은 5 7분이었다.

\begin{tabular}{|c|}
\hline $\begin{array}{l}\text { Introduction } \\
\text { - Conversation about OMT homework }\end{array}$ \\
\hline $\begin{array}{l}\text { Development } \\
\text { - Non-speech oral motor exercises } \\
\text { - OMT for articulation /i/ } \\
\text { - Motor-Phonetic \& phonological approach } \\
\text { - Phonetic placement } \\
\text { - Auditory discrimination: error sound vs. correct sound } \\
\text { - Shaping techniques } \\
\text { - Drill play with reinforcement }\end{array}$ \\
\hline $\begin{array}{l}\text { Evaluation } \\
\text { - Feedback about correct sound in contexts } \\
\text { - OMT homework instructions } \\
\text { - Planning activity as a reinforcer in next session }\end{array}$ \\
\hline
\end{tabular}

Figure 1. Intervention protocol. OMT: Oral Motor Training

\section{연구 설계 및 절차}

\section{실험 설계}

본 연구에서는 구강운동 훈련을 사용한 조음 치료가 설측음 화를 보이는 3급 부정교합 아동의 조음 정확도와 왜곡 오류 감 소에 미치는 효과를 알아보기 위하여 단일 사례 실험 설계(single case experimental design)의 ABA 설계를 사용하였다(Figure 2). 본 연구는 기초선, 중재, 유지의 3단계로 나누어 진행되었다.

\section{연구 절차}

기초선 단계에서는 중재를 실시하지 않았으며, 단어 및 문장 수준에서의 조음 정확도 및 설측음화 왜곡 오류 빈도를 평가하 기 위해 대상 아동의 말소리 평가만이 3회에 걸쳐 실시되었다. 중재 단계에서는 전체 대상 아동에게 동일하게 $\mathrm{OMT}$ 를 사용한 조음 치료가 총 12 회기 동안 실시되었다. 중재 단계의 회기 진 행은 1 회기당 40 분씩 매주 3 회에 걸쳐 개별적으로 이루어졌다. 중재 단계에서의 말소리 평가는 $2,4,6,8,10,12$ 회기, 총 6 회 실시되었다. 중재를 철회한 유지 단계에서는 중재 종료 후 2주 일이 지난 다음 매주 1 회씩 3 주에 걸쳐 기초선 단계의 조건과 동일하게 중재 없이 말소리 평가만 실시되었다.

전체 실험 회기는 $\mathrm{G}$ 광역시의 $\mathrm{E}$ 의사소통연구소의 조용하고 밝은 실내에서 실시하였으며, 검사나 중재에 필요한 최소한의 가구 및 자료만이 배치된 상태에서 개별적으로 이루어졌다. 기 초선 단계, 중재 단계, 유지 단계의 검사 실시는 말소리 장애 진 단평가 및 치료에 5년 이상 경력이 있고 언어치료학 석사학위를 가진 언어재활사(1급)가 하였고, 중재 단계의 중재는 말소리 장 애 진단평가 및 치료 경력 4년의 대학원생인 언어재활사(2급)가 담당하였다.

각 단계에 걸친 모든 검사는 말소리 분석을 위해 보이스 레 코더(ICD-UX400F, SONY, Shibuya, Japan)로 녹음하였고, 중

Baseline phase (phase A1)

- 2 variables were assessed at 3 data points

- No-intervention baseline phase

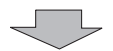

Intervention phase (phase B)

- 2 variables were assessed at 6 data points

- $12 \mathrm{OMT}$ and articulation therapy sessions

Maintenance phase (phase A2)

- 2 variables were assessed at 3 data points

- No-intervention withdrawal phase

Figure 2. ABA design for single case assessments. OMT: Oral Motor Training. 
재 단계의 중재 충실도를 평가하기 위해 모든 중재 회기의 중재 실 시는 디지털 캠코더(Xacti VPC-CA 100, SANYO, Osaka, Japan) 로 녹화하였다.

\section{자료 분석}

검사 시 검사자가 즉석에서 아동이 오조음한 말소리를 검사 지에 기재하였으며, 검사 실시 후 2 3일 내에 검사자와 연구자 가 독립적으로 녹음된 자료를 컴퓨터로 옮겨 들으면서 조음 평 가 결과를 각기 재확인하거나 기재하였다.

OMT를 사용한 조음 치료의 중재 효과를 알아보기 위해 평 가한 조음 정확도는 목표 음소인 초성 및 어중 초성 /ㄷ/, /ᄄᄄ/, /E/, /ㄴ/, /리, /ㅈ/, /ㅉ/, /ㅊ/, /ㅅ/, /ㅆ/의 전체 발음 횟수에 대한 목 표 음소들의 정조음 횟수 비율로 측정하였다. 조음 정확도를 구하는 공식은 '(정조음 횟수/음소의 발음 횟수) $\times 100$ '이다.

\section{신뢰도 및 중재 충실도}

검사자는 기초선, 중재, 유지 단계의 각 회기마다 녹음된 자료 전체를 다시 들으며 같은 방법으로 평가하고 계수하여 평가가 완성된 자료와 비교한 후 일치도를 계산하였다. 조음 정확도와 설측음화 왜곡 오류에 대한 평가자 내 신뢰도는 각각 $98,100 \%$ 를 나타내었다.

전체 자료에 대해 연구자(언어재활사 1급)의 평가 결과와 검 사자(언어재활사 1 급)의 평가 결과를 비교하여 일치도를 계산 하였다. 조음 정확도와 설측음화 왜곡 오류에 대한 평가자 간 신뢰도는 각각 $99,100 \%$ 를 나타내었다.

중재자(언어재활사 2급)가 중재를 정확하게 실시하였는지 조 사하기 위하여 연구자가 중재 영상 자료를 보며 중재 충실도를 평가하였다. 먼저 $\mathrm{OMT}$ 를 사용한 조음 치료에 대하여 구강운동 및 모음 훈련 4단계, 음절 수준 2단계, 단어 수준 2단계, 문장 수 준 2 단계, 총 10 단계로 나누고 각 단계에 해당하는 문항 10 개를 구성하여 체크 리스트 용지를 만들었다. 연구자는 매 회기마다 언어재활사의 중재에 대해 중재 절차가 바르게 수행된 경우 $\bigcirc$ 로 표기하고 바르게 수행되지 않은 경우 $\times$ 로 표기하였다. 중재 충실도는 중재를 바르게 실시한 수를 전체 실시한 수로 나눈 후 100을 곱하여 구하였다. 중재 충실도는 평균 $99.2 \%$ 였다.

\section{RESULTS}

본 연구의 목적은 구강운동 훈련을 사용한 조음 치료가 치 경음과 경구개음에서 설측음화 왜곡 오류를 보였던 3 급 부정교 합 아동의 조음 정확도와 설측음화 오류에 미치는 효과를 알 아보는 것이었다. 본 연구의 결과는 조음 정확도의 향상과 설측 음화 왜곡 오류 빈도의 감소 순서로 제시되었다.

\section{조음 정확도의 향상}

Figure 3과 Figure 4는 기초선, 중재, 유지의 단계 동안 전체 대상 아동 3 명의 단어검사와 문장검사에서의 조음 정확도 변 화 양상을 각각 보여준다.

기초선 단계 동안 전체 대상 아동은 단어검사와 문장검사에 서 조음 정확도가 모두 동일하게 $0 \%$ 로 매우 열악하게 나타났다. 그러나 중재를 실시하자 대상 아동 모두에게서 단어 및 문장에 서의 조음 정확도가 증가하기 시작하여 꾸준한 증가 추세를 나 타내어 매우 높은 조음 정확도에 도달하였고, 이 정확도는 중재 를 철회한 단계에서도 높은 정확도로 유지되었다. 이 변화 양상 을 통해 전체 대상 아동에게서 나타난 단어 및 문장에서의 목표 음 조음 정확도는 매우 높은 비율로 향상되었음을 볼 수 있다.

전체 대상 아동이 전반적인 말소리의 자음 정확도에 어떤 변 화가 있는지 알아보기 위해 사전-사후 아동용 발음평가(APAC) 를 비교하였다(Table 2). 표준화 검사의 동형 검사를 짧은 기간 동안 반복 측정하는 것을 배제하기 위해 전체 대상 아동에게 사전-사후 대화검사의 주제를 다르게 제시하고자 연결발화 검 사 중 대화 과제를 실시하였다. 각 검사의 대화 주제는 3 명의 대 상 아동 모두 동일하게 사전 검사 ‘치과 병원', 사후 검사 '컴퓨터 게임'이었으며, 유지 단계의 마지막 회기 검사는 ‘바닷가'였다.

대상 아동 $\mathrm{A}$ 의 자음 정확도는 사전 $73.2 \%$, 사후 $95.0 \%$, 추적 검사 $94.3 \%$ 였고, 대상 아동 $\mathrm{B}$ 는 사전 $71.3 \%$, 사후 $94.1 \%$, 추적 검사 $93.9 \%$ 였으며, 대상 아동 C는 사전 $74.1 \%$, 사후 $93.3 \%$, 추 적 검사 $92.8 \%$ 로 나타나 전체 대상 아동 모두 사전 검사에 비해 사후 및 추적 검사에서 높은 비율의 자음 정확도를 나타냈다.

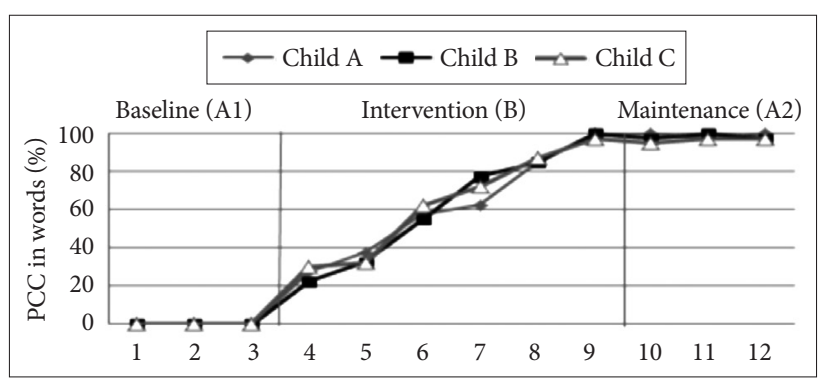

Figure 3. PCC in words of participants. PCC: percentage of correct consonants.

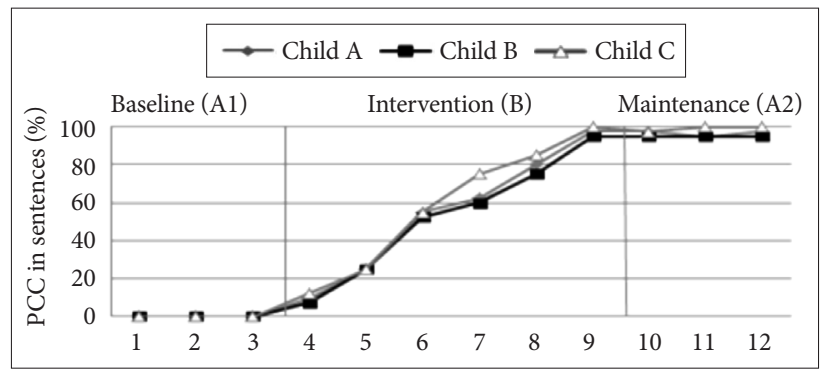

Figure 4. PCC in sentences of participants. PCC: percentage of correct consonants. 


\section{설측음화 왜곡 오류 빈도의 감소}

Figure 5는 기초선, 중재, 유지의 단계 동안 조음 정확도 평 가용 단어와 문장수준검사 전체에서 대상 아동 3 명의 설측음 화 왜곡 오류의 빈도 변화 양상을 보여준다.

기초선 단계 동안 전체 대상 아동은 설측음화 왜곡 오류 빈 도가 목표음 발음 기회 횟수의 최대치인 80에 달했으나 구강운 동 기능 훈련을 사용한 조음 치료를 실시하자 전체 대상 아동 모두에게서 설측음화 왜곡 오류 빈도가 급격히 감소하기 시작 하였고 모든 대상 아동에게 큰 변동 없이 꾸준히 감소 추세를 나타내어 그 빈도가 0에 도달하여 설측음화 왜곡 오류가 소거 되었음이 나타났다. 이 오류 빈도는 중재를 철회한 단계에서도 0으로 유지되어 /이/ 모음 환경의 목표음으로 구성된 단어 및 문장 수준에서 설측음화 왜곡 오류가 전체 대상 아동에게서 모두 소거되었음을 볼 수 있다.

전체 대상 아동에게서 나타난 전반적인 말소리의 오류 유형

Table 2. Results obtained by assessment of articulation and phonology for children before and after intervention

\begin{tabular}{lcccc}
\hline Index & Participant & $\begin{array}{c}\text { Before } \\
(\%)\end{array}$ & $\begin{array}{c}\text { After } \\
(\%)\end{array}$ & $\begin{array}{c}\text { 5-weeks follow-up } \\
(\%)\end{array}$ \\
\hline PCC & Child A & 73.2 & 95.0 & 94.3 \\
& Child B & 71.3 & 94.1 & 93.9 \\
& Child C & 74.1 & 93.3 & 92.8 \\
\hline
\end{tabular}

PCC: percentage of correct consonants

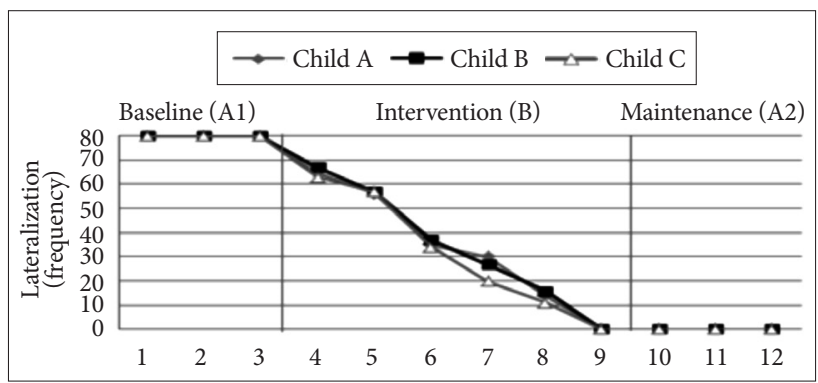

Figure 5. Frequency of lateralization distortion errors in word and sentence level in three participants in 3 phases of study.
을 알아보고자 아동용 발음 평가(APAC)의 연결발화 검사에서 나타난 사전-사후 말소리 오류의 변화를 비교하였다(Table 3). 사전에 나타난 오류 유형에는 설측음화 왜곡 오류와 치경 마찰 음의 치간음화 왜곡 오류가 있었으나, 사후에는 중재를 실시하 였던 설측음화 왜곡 오류는 발생하지 않았고, 중재를 실시하지 않았던 치경 마찰음의 치간음화의 오류는 개선되지 않은 것으 로 나타났다. 이 왜곡 오류는 /이/ 모음을 제외한 몇몇 모음 환 경에서 발생한 것으로 중재 목표가 아니었으며, 대상 아동 3 명 모두에게서 그 오류가 남아 있는 것으로 나타났다. 또한 사전에 /이/ 모음 환경의 탄설음 /리에서 나타났던 설측음화 왜곡 오류 가 사후에는 유음으로 대치되는 경우가 비일관적으로 나타났다. 전체 대상 아동 중 아동 $\mathrm{B}$ 는 사전에 다른 대상 아동과 마찬가지 로 /이/ 모음 환경의 탄설음 /리을 설측음화하여 설측 치경 탄 음 [I]로 왜곡하는 오류를 보였다가 사후에는 설측음화가 제거되 어 정조음하였으나, 비일관적으로 이를 다시 유음으로 대치하는 오류를 보이기도 하였다. 대상 아동 $\mathrm{A}$ 의 경우, 사전에 /이/ 모음 환경의 치경 마찰음 $/$ 씨이 치경 설측 마찰음 [ $\mathrm{b}]$ 나 [1]로 왜곡되 던 것이 사후에는 설측음화가 제거되어 정조음하는 경우도 있 었으나 비일관적으로 이를 다시 /시으로 대치한 경우가 있었다.

\section{DISCUSSIONS}

본 연구에서는 3 급 부정교합을 가진 유치열기 아동이 공통적 으로 편측 저작 습관과 편측화된 하악 폐구 습관, /이/ 모음 환 경의 치경음 및 경구개음을 설측음화하여 왜곡하는 사례들이 있어, 이들을 대상으로 올바른 목표 말소리 산출에 관여된 구 강운동에 초점을 두어 $\mathrm{OMT}$ 훈련을 사용한 조음 치료를 실시 하여 그 효과를 알아보았다.

그 결과 /이/ 모음 환경에서의 치경 마찰음 /ㅅ/, /ㅆ/, 치경 파 열음 /ㄷ/, /匹/, /E/, 치경 비음 /ㄴ/, 치경 유음 /ㄹ/, 경구개 파 찰음 /ㅈ/, / ㅉ/, /ㅊ/의 조음 정확도가 중재를 받은 후 전체 대상 아동에게서 높은 비율로 향상되었다. 또한 /이/ 모음 환경의 설

Table 3. Speech sound errors before and after intervention

\begin{tabular}{|c|c|c|}
\hline Phoneme & Before & After \& 5-weeks follow-up \\
\hline $\begin{array}{l}\text { ス, 不之 } \\
[\mathrm{tc}],[\mathrm{d}]] /\left[\mathrm{tc}^{*}\right],\left[\mathrm{tc}^{\mathrm{h}}\right]\end{array}$ & Distorted [dF] [t [t] in vowel [i] environments & No error \\
\hline $\begin{array}{l}\text { ᄃ, 匹, E } \\
{[\mathrm{t}],[\mathrm{d}] /\left[\mathrm{t}^{*}\right],\left[\mathrm{t}^{\mathrm{h}}\right]}\end{array}$ & Distorted [d $\overline{3}][\mathrm{tt}][\mathrm{t} T]$ in vowel [i] environments & No error \\
\hline $\begin{array}{l}\text { ᄂ } \\
{[\mathrm{n}]}\end{array}$ & Distorted [ $\mathrm{n}$ in vowel [i] environments & No error \\
\hline $\begin{array}{l}\text { ᄅ } \\
{[\mathrm{r}]}\end{array}$ & Distorted $[\mathrm{I}]$ in vowel $[\mathrm{i}]$ environments & Replaced by [l] in vowel [i] \\
\hline 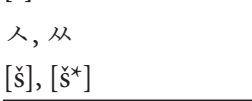 & $\begin{array}{l}\text { Distorted }[\mathrm{b}][\mathrm{1}] \text { in vowel [i] environments } \\
\text { Distorted }[\Theta] \text { in some vowel environments but [i] }\end{array}$ & $\begin{array}{l}{\left[\mathrm{s}^{*}\right] \text { : replaced by }[\mathrm{s}] \text { in vowel }[\mathrm{i}]} \\
\text { Distorted }[\Theta] \text { in some vowel environments but }[\mathrm{i}]\end{array}$ \\
\hline
\end{tabular}


측음화 왜곡 오류 빈도가 중재를 받은 후 전체 대상 아동에게 서 소거되었다. 그리고 조음 정확도의 향상과 설측음화 왜곡 오류 빈도의 감소는 중재 후에도 유지되었다. 반면, 나이에 적 절한 왜곡 오류일 뿐 아니라 /이/ 모음 환경과 관련된 설측음화 오류가 아닌 이유로, 중재할 때 목표로 삼지 않았던 치경 마찰 음의 치간 마찰음화 왜곡 오류는 중재 종료 후에도 소거되지 않았다. 또한 /이/ 모음 환경의 탄설음 [r]과 치경 찰음 [ [*]는 설 측음화 왜곡 오류가 소거되긴 하였어도 각기 유음 [1]와 [s]로 대 치되는 오류가 대상 아동 B와 C에게서 비일관적으로 나타났다. 이러한 결과는 구강 구조의 기질적 결함을 지닌 3급 부정교합 아동이 특정 말소리를 조음하는 데에 필요한 정확한 구강운동 에 문제를 보이는 경우 OMT를 사용하여 조음 치료를 실시하 는 것이 오조음 개선에 효과적일 수 있음을 시사한다. 이를 선 행연구에 비추어 논의하고 임상적 시사점과 연구의 한계 및 제 언을 제시하고자 한다.

첫째, 본 연구의 전체 대상 아동은 비구어적인 구강운동 중 편측 저작 습관과 하악 폐구 시 편측화 습관이 있었고, 구어적 구강운동 중에는 폐모음이자 고모음이면서 전설모음인 /이/ 모 음의 환경에서 혀끝 및 혀 등위를 상악 치경이나 경구개 부근까 지 들어올려 조음하는 구강자음의 설측음화된 조음 왜곡이 있 었다. 즉, 턱과 입술이 닫히는 움직임과 위치, 그리고 혀가 상악 궁에 근접하여 전방에 위치할 때 조음기관의 편측화된 왜곡이 비구어 및 구어에서 모두 나타났던 것이다. 이러한 점을 근거로 $\mathrm{OMT}$ 를 조음 치료에 적용하여 실시하였고, 그 결과 말소리 왜 곡 오류의 감소와 조음 정확도 향상에 효과가 있었다. 이는 구 강 구조의 기질적 결함에 의해 구강운동 기능이 전형성에서 벗 어나 말소리 산출에 왜곡을 나타냈던 아동을 대상으로 OMT 방식을 적용하여 조음 치료를 실시한 후 말소리 산출에 개선을 보였다고 보고한 선행연구 결과와 일치한다(Derakhshandeh et al., 2016; Jeon \& Seo, 2007; Lee \& Kim, 2001).

Derakhshandeh et al.(2016)의 연구에선 구강 구조의 기질적 결함과 연인두 기능부전을 가진 구개열 아동에게서 보상 조음 및 과비음 오류가 나타나 이를 개선하기 위해 비구어적 과제를 통해 구강운동을 훈련하고, 목표 말소리 산출에 직접적으로 요 구되는 구어적 구강운동의 훈련을 병행하여 말소리 산출을 유 도한 후 목표음 산출 언어 단위를 점차 증가시킨 결과, 왜곡이 나타났던 비구어적인 구강운동 기능의 개선뿐 아니라 말소리 의 왜곡 오류가 감소되는 효과가 있었다. Lee \& Kim(2001)은 보상 조음을 하는 구개열 아동을 대상으로 성문 파열음 왜곡 오 류를 개선하기 위해 성대 이완 훈련을 한 후, 목표 말소리 산출 을 유도하여 조음 정확도 향상과 왜곡 오류 감소의 효과가 있었 다. Jeon \& Seo(2007)는 경직형 뇌성마비 아동을 대상으로 마비 및 약화를 보이는 호흡 및 구강운동을 강화하는 OMT를 실시하
고, 여러 말소리에 걸친 조음기관의 움직임에 초점을 둔 훈련을 실시한 결과, 전반적인 말소리의 자음 정확도 향상과 호기 및 발성 시간의 증가에 효과가 있었다.

따라서 기질적 결함을 가진 아동에게서 구강운동 문제가 나 타나고, 말소리 산출에 필요한 조음기관의 움직임과 위치에 문 제가 따르며, 말소리 왜곡 오류가 발생된 경우라면, OMT를 조 음 치료에 집중적으로 적용하는 것을 고려해 볼 수 있을 것이라 여겨진다. 더욱이 구강운동 기능이 부족한 아동의 경우, 전통적 조음 치료에서 조음점 지시법(phonetic placement)을 비롯한 여러 기법들이 제공하는 청각, 촉각 및 시각적 자극, 구어적 설 명으로는 목표 말소리 산출을 향상시키는 데에 제한이 있을 수 있고 그 진전 또한 느리게 나타날 수 있다(Bahr \& RosenfeldJohnson, 2010). 그러므로 치료 효과 제고를 위해 3급 부정교 합을 가진 어린 아동의 구강운동 상태를 점검하고, $\mathrm{OMT}$ 를 조 음 치료에 도입해 볼 것을 고려해 볼 수 있다고 생각된다. 특히 나 3 급 부정교합을 가진 유치열기 아동의 경우 잘못된 구강 습 관이 호발하므로(Jung et al., 2015), 구강운동 기능과 조음의 연관성을 관찰하여 중재 계획을 세울 필요가 있을 것이다.

둘째, 본 연구의 중재 단계에서는 /이/ 모음 환경의 치경음 및 경구개음의 정조음을 목표로 중재를 실시하였고, 중재 단계가 종료된 후 목표 말소리 조음이 개선되는 효과가 있었다. 그러나 중재하지 않았던 말소리 오류는 개선되지 않았는데, /이/ 모음 을 제외한 몇몇 모음 환경에서 나타났던 치경 마찰음의 치간음 화 왜곡은 개선되지 않은 채 그 오류가 전체 대상 아동에게서 남아 있었다. 이러한 결과는 본 연구에서 목표한 바에 따라 실 시한 중재가 목표음 조음 개선에 효과적이었음을 의미한다. 다 만 치경 마찰음의 치간음화는 6세 6세 5 개월 연령 범위의 아동 에게는 나이에 적절한 오류에 해당한다는 점(Kim et al., 2007) 을 고려하면 이 연령 범위에 해당하는 본 연구의 대상 아동에 대한 이러한 해석은 조심스럽게 여겨진다. 그러나 한편, 본 연구 의 대상 아동 중 일부가 /이/ 모음 환경에서 탄설음 [r]을 정조음 하기도 하고 유음 [1]로 대치하기도 하였으며, /이/ 모음 환경에서 마찰음 [ [*]를 정조음하기도 하고 $[\mathrm{s}]$ 로 대치하기도 한 점을 생각 해 보면, 말소리 오류가 발생한다 하더라도 비구어 및 구어에서 의 편측화된 구강운동의 왜곡과는 관련 없는 오류였음을 알 수 있다. 그러므로 결국 이러한 결과는 본 연구의 중재 단계에서 조음기관의 편측화된 운동의 올바른 위치와 움직임에 초점을 둔 OMT가 효과적일 수 있음을 시사한다.

더욱이 구강운동의 문제를 가진 아동을 대상으로 전통적 조 음 치료와 구강운동 치료를 실시하여 그 효과를 비교한 Lohman-Hawk(2007)는 구강운동 기능에 문제를 보이는 아동에게 는 비구어적 OMT에 국한된 치료뿐 아니라, 구어에서 특정 말 소리 산출에 요구되는 조음기관의 정확한 움직임과 위치를 촉 
진하는 $\mathrm{OMT}$ 가 필요하며, 이 훈련이 특정 음소의 조음에 관여 하는 구강운동 기능에 대한 인식과 정확성, 조음기관 간의 협 응에 이로울 수 있다고 하였다. 본 연구의 대상 아동 역시 구강 운동 문제를 가진 아동들로서 폐구에 관여되는 올바른 턱의 움직임 및 위치에서 /이/ 모음의 산출에 필요한 턱과 혀의 움직 임 및 위치를 OMT를 통해 연습하였다. 그리고 이 OMT에 왜 곡 오류를 보였던 자음 산출에 필요한 OMT를 통합하였다. 특 히 좁아진 구강 안에서 혀끝 및 등위를 상악 전방 부근에 들어 올려 접촉하거나 마찰시켜야 하는 구강자음의 조음에 관여된 일련의 위치와 움직임을 훈련하였다. 가령, /지/라는 음절 산출 에 요구되는 조음기관의 위치, 움직임, 그리고 각 기관 간의 협 응적인 구강운동의 일체를 한 번에 묶어 훈련하던 것이다. 따라 서 편측화된 저작 습관과 편측화된 하악 폐구와 같은 비구어적 구강운동에 왜곡을 보인 본 연구의 대상 아동들에게는 비구어 적 OMT뿐 아니라 구어적 OMT를 통한 조음 치료가 /이/ 모음 산출에 요구되는 조음기관의 왜곡 완화에 효과적이었다고 생 각된다.

본 연구의 한계와 제언은 다음과 같다. 본 연구의 전체 대상 아동이 공통적으로 3 급 부정교합의 문제와 비구어 및 구어 운 동에서의 편측화된 왜곡이 있었고, 이에 기반한 중재가 단일 대상 실험 설계에 의해 체계적으로 실시되었으나, 그 대상 수가 적어 연구의 결과를 일반화하는 데에 어려움이 따른다.

본 연구의 대상 아동이 갖는 여러 변인들(예, 전치부 반대교 합, 개교합) 중 어떠한 변인들이 비구어 및 구어 과제에서 조음 기관의 편측화된 왜곡에 기여하는지 밝혀진 바가 없어 그 원인 에 대한 분명한 설명에 제한이 따른다. Angel의 분류에 의한 부정교합과 말소리 산출 오류 간에는 유의한 상관이 없다고 보 고한 연구(Leavy et al., 2016)가 있으나 이는 혼합 치열기 이상 의 말소리 발달을 이미 마친 아동부터 성인에 이르는 연령을 대 상으로 한 연구이다. 또한 3 급 부정교합과 말소리에 관련된 악안 면 구강의 위치와 움직임의 관계에 관한 상술된 연구들은 3 급 부정교합이라는 변인만 고려되어 있어서 동반된 여러 유형의 교 합이나 습관과 같은 변인에 따른 정보를 알기 어렵다. 그러므로 본 연구의 중재를 어떤 하위 특성을 가진 3급 부정교합 대상 아 동에게 적용할 것인가를 판단하여 반복 연구를 실시하는 데에 한계가 따른다. 그러나 이러한 제한점에도 불구하고, 본 연구에 서 3 급 부정교합을 가진 대상 아동이 편측화된 저작 습관과 편 측화된 하악 폐구 습관, 그리고 편측화된 말소리 왜곡을 동시에 나타냈다는 점이 바로 적용 대상 선정 시 고려 사항이 될 것이 며, 이와 관련한 점은 향후 연구에서 확인해 볼 만하다.

또한 본 연구에서는 비구어적 구강운동과 구어적 구강운동 을 모두 훈련하였다. 조음 치료 효과 제고를 위해 선행연구 결 과를 종합적으로 검토하여 목표 말소리 조음 시 요구되는 구강
운동 훈련이 중요할 수 있음을 발견하고 구어적 OMT에 초점 을 두어 조음 치료를 실시하였다. 그러나 두 가지 OMT 변인에 관한 차별적 효과를 알기 위한 변인 통제는 하지 않았다. 그러 므로 기질적 결함을 가진 3급 부정교합 아동에게 이 두 가지 변인을 통제하여 비교하는 후속연구가 필요할 것이다. 다만, 비 구어적인 구강운동 연습만 별도로 실시하면서 조음 치료를 실 시하는 중재 프로그램이 효과적이라는 진실험 설계의 증거 기 반 실제 연구는 사실상 아직까지 찾아볼 수 없다는 주장이 있 으며(McCauley et al., 2009), OMT를 사용한 조음 치료가 구 강운동 기능에 문제가 없는 대상에게 효과적인 조음 개선을 가 져다 준다고 확증할 만한 증거 기반 실제 연구 또한 발견하기 어 렵다는 주장도 있으므로(Lof \& Watson, 2008; Ruscello, 2008), 확장된 후속연구를 위해서는 OMT 변인 및 연구 대상 관련 변 인의 선별과 통제에 세심한 주의가 필요할 것으로 보인다.

중심단어 : 말소리 장애·조음 치료·3급 부정교합·구강운동 훈련.

\section{REFERENCES}

Bahr, D. \& Rosenfeld-Johnson, S. (2010). Treatment of children with speech oral placement disorders (OPDs): A paradigm emerges. Communication Disorders Quarterly, 31(3), 131-138.

DeNinno, J. \& Gill, K. (1997). “Can Do" ${ }^{\circledR}$ Oral-Motor Fun Deck ${ }^{\circledR}$-Grades PreK2. Greenville, SC: Super Duper ${ }^{\circledR}$ Publications.

Derakhshandeh, F., Nikmaram, M., Hosseinabad, H. H., Memarzadeh, M., Taheri, M., Omrani, M., et al. (2016). Speech characteristics after articulation therapy in children with cleft palate and velopharyngeal dysfunction-A single case experimental design. International Journal of Pediatric Otorhinolaryngology, 86, 104-113.

Felício, C. M. \& Ferreira, C. L. (2008). Protocol of orofacial myofunctional evaluation with scores. International Journal of Pediatric Otorhinolaryngology, 72(3), 367-375.

Hoch, L., Golding-Kushner, K., Siegel-Sadewitz, V. L., \& Shprintzen, R. J. (1986). Speech therapy. Semin Speech Lang, 7(3), 313-326.

Jeon, B. U. \& Seo, J. E. (2007). The effect of respiration and oral motor training on correctness of consonants and the vocalization prolongation, for children with spastic cerebral palsy. Korean Journal of Physical, Multiple and Health Disabilities, 49, 135-160.

Jeon, G. S., Kim, D. C., Hwang, S. J., Shin, H. K., \& Kim, H. G. (2007). Acoustic characteristics of patients' speech before and after orthognathic surgery. Speech Sciences, 14(3), 93-109.

Johnson, N. C. \& Sandy, J. R. (1999). Tooth position and speech--is there a relationship? The Angle Orthodontist, 69(4), 306-310.

Jung, B. R., Kim, S., Jeong, T. S., \& Kim, J. Y. (2015). Maturation of the first molars in primary dentition with class III malocclusion. Journal of the Korean Academy of Pediatric Dentistry, 42(2), 144-150.

Kim, M. J., Pae, S. Y., \& Park, C, I. (2007). Assessment of Phonology and Articulation for Children. Seoul: Human Brain Research \& Consulting Co.

Kim, Y. T., Seung, T. J., \& Lee, Y. K. (2013). Preschool Receptive-Expressive Language Scale (PRES). Seoul: Seoul Community Rehabilitation Center.

Laine, T. (1987). Associations between articulatory disorders in speech and occlusal anomalies. European Journal of Orthodontics, 9(2), 144150.

Laine, T. (1992). Malocclusion traits and articulatory components of speech. European Journal of Orthodontics, 14(4), 302-309.

Leavy, K. M., Cisneros, G. J., \& LeBlanc, E. M. (2016). Malocclusion and its 
relationship to speech sound production: Redefining the effect of malocclusal traits on sound production. American Journal of Orthodontics and Dentofacial Orthopedics, 150(1), 116-123.

Lee, K. H. \& Kim, J. C. (1993). A radiographic study of tongue posture at rest position and during the phonation of $/ \mathrm{s} /$ in class III malocclusion. The Korean Journal of Orthodontics, 23(2), 179-197.

Lee, S. Y. \& Kim, Y. T. (2001). Effects of vocal relaxation treatment on the articulation accuracy and compensatory articulation of cleft palate children. Speech Sciences, 8(3), 185-200.

Lof, G. L. \& Watson, M. M. (2008). A nationwide survey of nonspeech oral motor exercise use: implications for evidence-based practice. Language, Speech, and Hearing Services in Schools, 39(3), 392-407.

Lohman-Hawk, P. (2007). Efficacy of Using an Oral-Motor Approach to Remediate Distorted / $r /$ Boston, MA: ASHA Annual Convention.

Mackie, E. (1996). Oral-Motor Activities for School-Aged Children. (1st ed.). (pp. 9-21). East Moline, IL: Linguisystems.

McCauley, R. J., Strand, E., Lof, G. L., Schooling, T., \& Frymark, T. (2009). Evidence-based systematic review: effects of nonspeech oral motor ex- ercises on speech. American Journal of Speech-Language Pathology, 18(4), 343-360.

Ruscello, D. M. (2008). Nonspeech oral motor treatment issues related to children with developmental speech sound disorders. Language, Speech, and Hearing Services in Schools, 39(3), 380-391.

Sargenti, T. (2011). The effects of oral-motor treatment in remediating speech sound disorders for children who exhibit a lack of sufficient oral-motor control (unpublished master's thesis). William Paterson University, Wayne, NJ.

Shin, M. J. \& Kim, Y. T. (2007). Urimal Workbook of Articulation and Phonology $(U-W A P)$. Seoul: Hakjisa Korea Psychological Service.

Yang, K. H. (1996). A study on the tongue posture in children with class III malocclusion. Journal of the Korean Academy of Pediatric Dentist$r y, 23(1), 24-34$

Yang, K. H. \& Choi, N. K. (2000). The study on the orthodontic patients who visited department of pediatric dentistry, Chonnam National University Hospital. Journal of The Korean Academy of Pediatric Dentistry, 27(1), 113-121. 
APPENDIX

Test for Articulation Accuracy and Lateralization Distortion Errors

\begin{tabular}{|c|c|c|c|c|}
\hline \multirow{3}{*}{$\frac{\text { Target sound }}{\curlywedge}$} & \multicolumn{4}{|c|}{ Words } \\
\hline & \multicolumn{2}{|c|}{ Word initial syllable initial } & \multicolumn{2}{|c|}{ Word medial syllable initial } \\
\hline & 신발 & 시소 & 가시 & 화장실 \\
\hline$\mu$ & 씽씽 & 씨름 & 색시 & 아저씨 \\
\hline$\sqsubset$ & 디딤돌 & 디지몬 & 잔디 & 라디오 \\
\hline$\llbracket$ & 띠띠 & 띵똥 & 땀띠 & 검은띠 \\
\hline E & 티비 & 티셔츠 & 파티 & 반팔티 \\
\hline\llcorner & 닌자고 & 니모 & 덧니 & 할머니 \\
\hline ᄅ & 리어카 & 리본 & 머리 & 코끼리 \\
\hline$\pi$ & 진짜 & 지우개 & 바지 & 오징어 \\
\hline य & 찌개 & 찐빵 & 팔찌 & 꼴찌 \\
\hline ᄎ & 칫솔 & 침대 & 아침 & 스위치 \\
\hline \multirow{2}{*}{ Target sound } & \multicolumn{4}{|c|}{ Sentences } \\
\hline & \multicolumn{2}{|c|}{ Word initial syllable initial } & \multicolumn{2}{|c|}{ Word medial syllable initial } \\
\hline \multirow[t]{2}{*}{$\curlywedge$} & \multicolumn{2}{|c|}{ 시소를 타요 } & \multicolumn{2}{|c|}{ 가시가 뾰족해요 } \\
\hline & \multicolumn{2}{|c|}{ 신발을 벗어요 } & \multicolumn{2}{|c|}{ 화장실에 들어가요 } \\
\hline \multirow[t]{2}{*}{$\mu$} & \multicolumn{2}{|c|}{ 씨름을 해요 } & \multicolumn{2}{|c|}{ 아저씨께 인사해요 } \\
\hline & \multicolumn{2}{|c|}{ 씽씽 달려요 } & \multicolumn{2}{|c|}{ 색시는 신부예요 } \\
\hline \multirow[t]{2}{*}{$\sqsubset$} & \multicolumn{2}{|c|}{ 디지몬을 사요 } & \multicolumn{2}{|c|}{ 라디오를 들어요 } \\
\hline & \multicolumn{2}{|c|}{ 디딤돌을 놓아요 } & \multicolumn{2}{|c|}{ 잔디를 깎아요 } \\
\hline \multirow[t]{2}{*}{$\llbracket$} & \multicolumn{2}{|c|}{ 띵똥하고 울려요 } & \multicolumn{2}{|c|}{ 검은띠를 따요 } \\
\hline & \multicolumn{2}{|c|}{ 띠띠 소리 나요 } & \multicolumn{2}{|c|}{ 땀띠가 나요 } \\
\hline \multirow[t]{2}{*}{ E } & \multicolumn{2}{|c|}{ 티비를 켜요 } & & \\
\hline & & & & \\
\hline\llcorner & & & & \\
\hline & & & & \\
\hline ᄅ & & & & \\
\hline & & & & \\
\hline$\pi$ & & & & \\
\hline & & & & \\
\hline य & & & & \\
\hline & & & & \\
\hline $\bar{\lambda}$ & & & & \\
\hline & & & & \\
\hline
\end{tabular}

